\title{
IDENTIFICATION AND ANALYSIS OF RISK FACTORS IN THE PROCESS OF RECEIVING GOODS INTO THE WAREHOUSE
}

\author{
Ewa KULIŃSKA*, Julia GIERA** \\ Opole University of Technology, Faculty of Production Engineering and Logistics, POLAND \\ *e-mail: e.kulinska@po.opole.pl \\ **e-mail: j.giera@doktorant.po.edu.pl
}

\begin{abstract}
The process of receiving goods into the warehouse is the first stage of warehouse management. Correct receipt of fast-moving goods is the key element of the storage process as well as of the entire supply chain, which is why it is so important to avoid any disruptions at this stage. In order to identify and analyze the associated risk factors, two quality risk management methods were applied: a risk map and the fast-moving consumer goods (FMCG) method, whose goal was to determine the magnitude of individual risk factors. The presented findings indicate which risk factors are the most hazardous to the goods receipt process. A correlation was found to exist for the value of goods as well as the continuity of the consequences entailed by the occurrence of a specific factor. The article presents preventive mechanisms as a risk management tool.
\end{abstract}

Keywords: warehouse management, goods receipt process, risk.

JEL: B40, D22, D30.

\section{$1 \quad$ Introduction ${ }^{1}$}

Warehouse management is an indispensable element of the supply chain. Correct receipt of goods into the warehouse is of key importance for the entire storage process, and further functioning of the warehouse depends on this stage. Errors made at this point will affect the subsequent phases as well as the entire supply chain.

This article aims to identify and analyze risk factors in the process of goods receipt in the examined enterprises using two qualitative methods: a risk map and FMEA (Fast Moving Consumer Goods) in production warehouses and storage facilities offering outsourcing services. The resulting findings provide the basis for defining preventive mechanisms for risks occurring in the process of receiving goods into the warehouse.

The conducted research revealed that the magnitude of effects (consequences) and the probability of risk factors depend on the value of goods as well as the continuity of consequences that a given factor entails. The applied methods showed which risk factors are the most severe for the organization. A risk anal-

\footnotetext{
1 The project was financed from the funds of the National Science Center granted on the basis of decision number DEC2012/05 / B / HS4 / 04139; project manager: E .Kulińska.
}

ysis should help identify the best risk management method and indicate which risk factors are the most hazardous in the process of receiving goods into the warehouse.

The findings presented in the article provide the basis for a research project to be launched in the near future. The study is part of the scientific research carried out in cooperation with the Polish National Science Center. The aim of the research project is to present the significance of risk management in the storage process. Correct functioning of warehouse management affects the entire supply chain; hence, it is so important to address this topic in the field of logistics. A critical element in the storage process is the receipt of goods into the warehouse, the reason for which this stage is the foundation for the scientific research at hand, with this article being crucial to the launch of the abovementioned research project.

\section{The process of receiving goods into the warehouse}

The continuous flow of raw materials, finished products, and information is necessary for the proper functioning of a logistics system. In practice, it is not possible for raw materials or finished products to be 
moved constantly from the producer, through distribution channel links, all the way to the recipient (Figurski and Niepsuj, 2017). Therefore, the key element in any supply chain is warehouse management, with the term warehouse referring to the facility where movable goods are stored.

A warehouse system in modern storage facilities consists of a set of operational resources, both fixed and mobile, located in the building and its surroundings. The system is to facilitate the free flow of goods and information by taking into account the most important criterion, that is, time and costs, as well as managing a relevant supply chain (Figurski and Niepsuj, 2017).

Warehouse management relies on the storage process. The PN-84/N-01800 standard defines the concept of storage process (sometimes referred to as warehouse process) as a set of technological activities performed in a specific order (Jacyna, Bobiński and Lewczuk, 2017). The storage process is also a set of operational activities related to the receipt, storage, picking, and release of stock from the warehouse while meeting certain organizational and technological requirements. The storage process encompasses not only the flow of goods but also information (Kisperska-Moroń and Krzyżaniak, 2009).

Regardless of the location of the warehouse in a logistics system, the correct flow of input and output information is necessary for the proper functioning of the system. The information should concern both the stored inventories and the quantity of available materials, along with the existing demand for them (Jacyna, Bobiński and Lewczuk, 2017). It is important that warehouse data show the actual state instead of overestimations.

Warehouses in supply chains serve the following functions:

- separation - completion and transport of goods to subsequent links in the supply chain,

- processing - production processes enabling to differentiate the product,

- increasing the availability of materials - spatial distribution of goods,
- buffering - leveling inequalities in the flow of goods and their storage and then transporting as needed (Jacyna-Gołda, 2015).

The first stage in the storage process is receiving goods into the warehouse. It involves the receipt of products from suppliers according to specific delivery conditions. When receiving goods, it is important to correctly identify them and to control both their quality and quantity. Goods verification is aimed at revealing surpluses and shortages, resulting in their selection for further storage (Michlowicz, 2012). In the process of receiving goods, the process of responsibility for stored goods begins.

The following stages are distinguished in the process of receiving goods into the warehouse:

- receiving and identifying goods,

- unloading goods from the means of external transport,

- drafting documentation for the receipt of goods,

- repacking the load onto internal transport units,

- preparing goods for further transport.

A complete identification of goods during their receipt into the warehouse should include:

- product name,

- manufacturer's name,

- production date,

- expiry date,

- serial number,

- batch,

- quantity of stock,

- product quality,

- country of origin.

Once the above items are met and all the aspects are consistent with the documentation for receiving goods into the warehouse, this is when delivery compliance takes places.

Depending on the type of supplier, two types of goods can be distinguished:

- external - receipt of goods from an external supplier of goods,

- internal - receipt of goods from within the enterprise implementing the relevant storage process 
(Nowakowska-Grunt, Mesjasz-Lech and Kot, 2017).

The moment of delivering goods to the warehouse marks the beginning of the stage of goods receipt into the warehouse.

This stage is considered to be completed after the processes of unloading, identification, quantitative and qualitative control, sorting, preparing goods for a storage zone, and transferring them to that zone have been performed.

\section{Risk management in the logistics storage process}

Risk is an inseparable element in logistics, referring to the possible occurrence of an event that will affect the organization's goals. Both the probability (likelihood) and the effect (outcome, consequence) of risk can be measured, with risk being mainly seen as a negative phenomenon to be avoided (Kulińska, 2011). The difference between risk and uncertainty was determined by Knight (1965), who defined risk as a measurable phenomenon and uncertainty as an immeasurable one.

Risk management should be purposeful and planned (Fig. 1). Proceedings should be systematic and have a long-term outlook. An important factor is also the integration of all enterprises in order to provide a comprehensive company management system (Kulińska, 2011).

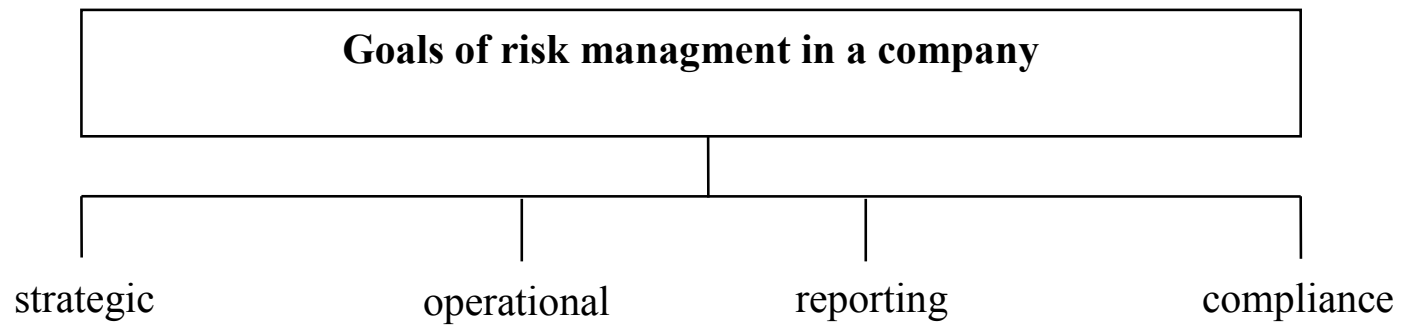

Figure 1. Goals of risk management in a company

(Source: Own study based on: Kulińska, 2010)

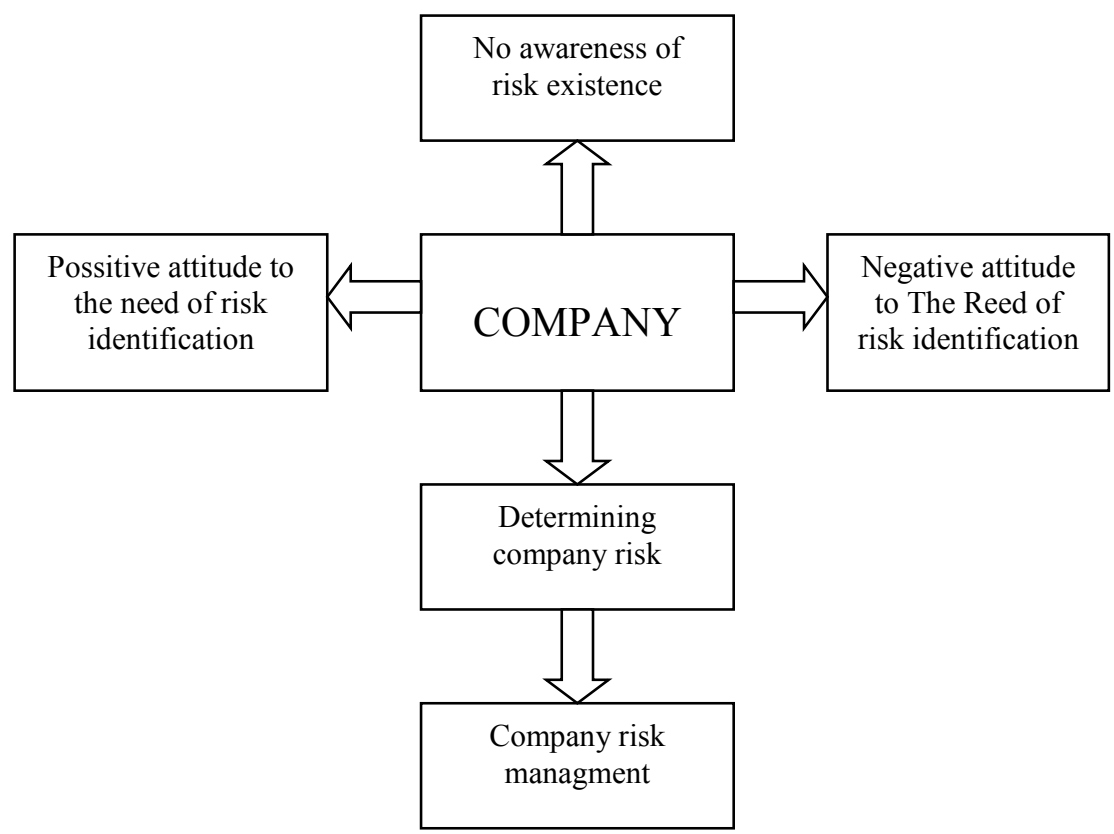

Figure 2. Company's attitude to the risk management process

(Source: Own study based on: Kulińska, 2010) 
According to Brown and Chong, a risk management system consists of four stages: identification, classification, analysis, and response to risk. The methods of approach to risk proposed by these authors are avoidance, lack of action; mitigation, reduction of risk exposure; dissipation, insurance against liability; and risk absorption, strengthening of the enterprise to minimize the impact of the risk on the organization (Brown and Chong, 2000).

The main problem in risk management concerns determining the location of risk occurrence as well as its characterization. These issues were outlined in Fig. 2 (Kulińska, 2009).

The occurrence of risk in the storage process is reported at a high level. Factors that affect the increase in risk probability are the long period of storage of goods and shipment of goods from one warehouse to another organization's production warehouse or to the next link in the supply chain (Kisperska-Moron and Krzyżaniak, 2009).

In order to maintain a high level of customer service and to bring financial benefits to enterprises, an adequate level of inventory in a warehouse is required. It should be remembered that stockpiling also means costs for the organization. The key element is maintaining an appropriate level of inventory, which translates into the optimal level of customer service, keeping in mind the minimization of the costs of keeping goods in the storage facility.

Irregularities may occur at any stage of the storage process. To counteract their negative effects, qualified staff and self-control of employees during warehouse operations are important. Table 1 shows the potential errors in the process of receipt of goods into the warehouse and the possible effects and causes of such events (Wasilewski, Witkowski and Huk, 2016)

Table 1. Disruptions in the process of receiving goods (Source: Own study based on: Nowakowski, 2011)

\begin{tabular}{|l|l|l|l|}
\hline \multicolumn{1}{|c|}{ Stage } & \multicolumn{1}{|c|}{ Disruption } & \multicolumn{1}{c|}{ Possible effect } & \multicolumn{1}{c|}{ Possible cause } \\
\hline \multirow{4}{*}{ Receipt of goods } & $\begin{array}{l}\text { Receiving unsolicited } \\
\text { goods }\end{array}$ & $\begin{array}{l}\text { Lack of raw materials } \\
\text { required in the production } \\
\text { process or lack of finished } \\
\text { product ready for the re- } \\
\text { cipient }\end{array}$ & $\begin{array}{l}\text { Incorrect labeling by the } \\
\text { manufacturer or incorrect } \\
\text { identification by ware- } \\
\text { house employees }\end{array}$ \\
\cline { 2 - 4 } & $\begin{array}{l}\text { Receiving goods with in- } \\
\text { complete or ill-filled doc- } \\
\text { umentation }\end{array}$ & $\begin{array}{l}\text { Lack of necessary data for } \\
\text { company departments, for } \\
\text { example, finance depart- } \\
\text { ment }\end{array}$ & $\begin{array}{l}\text { Incorrect verification } \\
\text { of shipping documents }\end{array}$ \\
\cline { 2 - 5 } & $\begin{array}{l}\text { Receiving an incorrect } \\
\text { quantity of goods }\end{array}$ & Lack or excess of products & $\begin{array}{l}\text { Incorrect calculation of the } \\
\text { quantity of goods received }\end{array}$ \\
\cline { 2 - 5 } & $\begin{array}{l}\text { Receiving goods that are } \\
\text { labeled incorrectly }\end{array}$ & $\begin{array}{l}\text { Discrepancy in individual } \\
\text { batches of raw materials }\end{array}$ & $\begin{array}{l}\text { An error made by the per- } \\
\text { son who received the raw } \\
\text { materials }\end{array}$ \\
\hline
\end{tabular}

The main factor prompting disruptions in the storage process is incorrect or insufficient training of staff, the use of inadequate organizational structures, or errors committed in the flow of information.

The factor that can cause risk in the storage process is the supply zone, which is directly related to the inventory. The first type of risk relates to fluctua- tions in the demand for specific goods. The second type of hazards concerns random fluctuations in time between purchases of a lot of products and delivery of goods to the client, meaning that it concerns the period of waiting for delivery (Wasilewski, Witkowski and Huk, 2016). 
The combination of processes and operations whose goal is to convert a raw material into food (finished product) is called the food supply chain. It is an interconnected network of cooperating entities whose aim is to make products available to consumers. The food chain starts with an agricultural enterprise, a producer/manufacturer, after which the raw material coming from this entity is processed in order to produce a consumable product. Goods need to pass through individual logistics procedure, including the storage process (Dani, 2016).

The identified risk factors in the process of receiving goods into the warehouse relate to products forming part of the fast-moving consumer goods (FMCG) industry in which supply chains are dynamic. The quick transferability of products results in the necessity of constant replenishment of stock. This is an area of fast-rotating products, which is why FMCG are purchased by clients frequently (Liczmańska, 2016). Food products have expiration dates; hence, they must be delivered quickly and reach consumers in appropriate conditions, bearing in mind their health and well-being.

Enterprises that store FMCG handle mainly readymade products and raw materials. As far as finished goods are concerned, warehouses tend to store food products. This category of goods also includes cosmetics, detergents, cigarettes, and alcohol. FMCG is sometimes referred to as the high-rotation goods industry, where products usually have a short life cycle (Miller, 2016). This is why the streamlining of supply chains is important in logistics in which the storage of FMCG is an important element.

A large number of products with a relatively low value of goods generate a large stream of product flows between individual logistics processes; therefore, the demand for storage services for FMCG remains constantly high.

The daily rotation of products from the FMCG sector in warehouses is very large, both in terms of the volume of deliveries and product releases. With the constant high volume of deliveries in the storage facility, the probability of error is high. There are two groups of risk occurring in food supply chains:

1) a discrepancy between demand and supply for products,

2) disruptions in deliveries (Sheffi, 2005).

These groups are susceptible to a number of risk. In order to provide enterprises with adequate protection against the occurrence of risk factors, the company should analyze risk factors in the warehouse process to develop a risk management system.

\section{$5 \quad$ Storage companies}

Ten companies providing storage services in Poland participated in the study. Six of these organizations provide outsourcing services (marked with numerical numbers 1-6), while the remaining four are production warehouses (marked with letters A to D). The examined companies store finished goods of the FMCG category, that is, fast-moving consumer goods. All 10 warehouses meet the requirements of legal provisions for storage of FMCG products, in particular food products.

Each company has a closed warehouse, that is, a building with vertical and horizontal divisions. These are closed ground-floor warehouses. The companies have only one overground floor, which is the ground floor, whereas the lower surface is located on the level of the adjacent area. In terms of building height, they are tall as far as storage facilities go (from 7.2 to $25 \mathrm{~m}$ ). The block (two warehouses), shelf (four warehouses), and the mixed block/shelf (four warehouses) storage method are used in the warehouses.

Another parameter characterizing the examined warehouses is their intended use. They are industrial warehouses that are to ensure continuity of production by storing semifinished and finished products. Only deliveries of finished products to the examined companies were analyzed. 


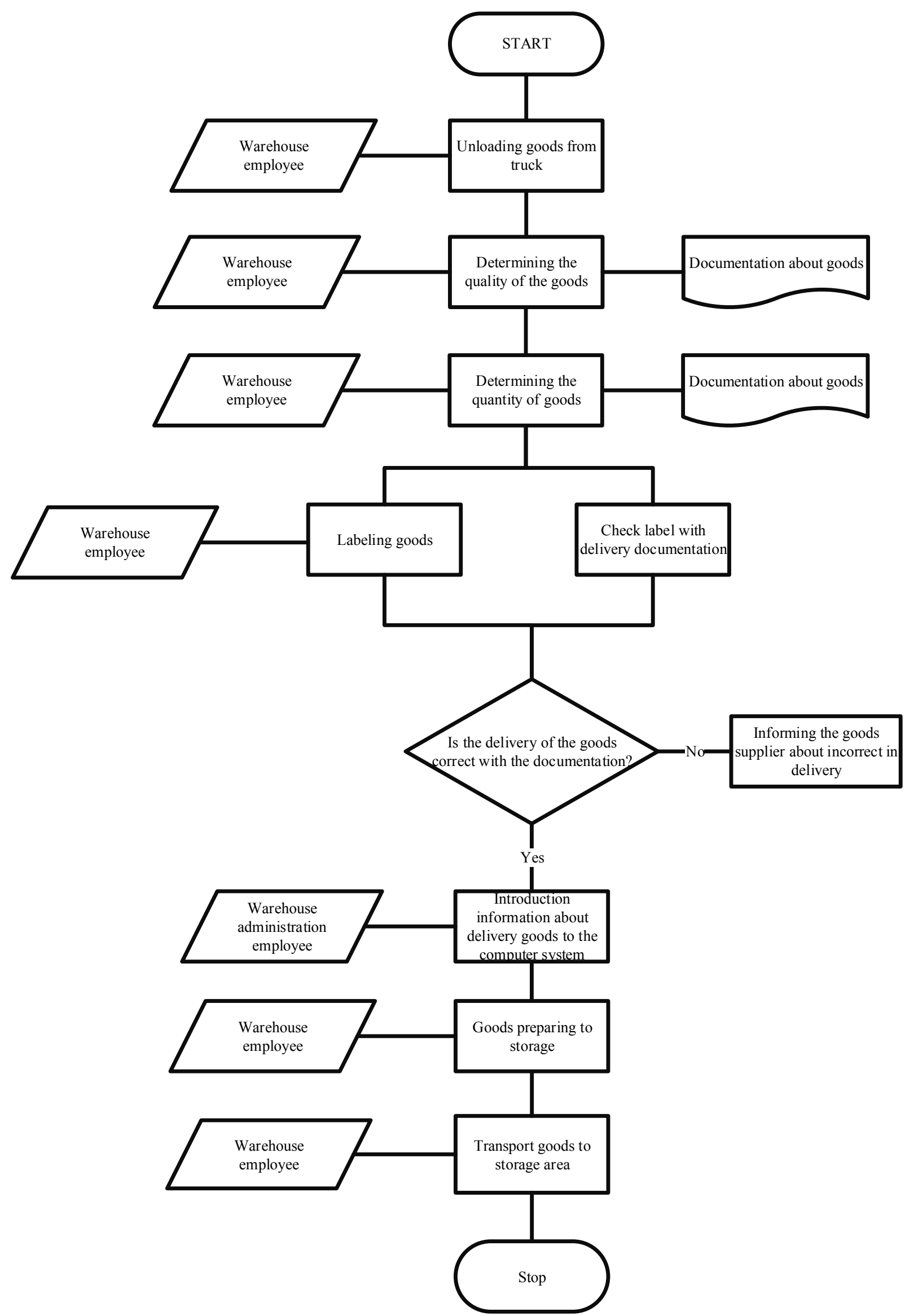

Figure 3. Block diagram of the process of receiving goods into the warehouse (Source: Own study) 
Owing to the form of stored goods, materials are stored in these warehouses in the form of a loading unit or, more specifically, goods are located on pallets: EUR, ISO, and CHEP. The maximum number of pallets that can be accommodated by the storage facilities ranges from 2,000 to 30,000 EUR-pallets.

The investigated period of supplies is 3 months. The statistical data shows that the daily number of deliveries for Companies 3, 4, 5, A, B, and D is between 15 and 20, whereas for Companies 1, 2, 6, and $\mathrm{C}$, it ranges from 18 to 25 deliveries. Only deliveries received between 6 a.m. and 2 p.m. are taken into account. The risk of receiving supplies at night is not analyzed.

The man-to-goods storage method and automatic identification of goods are used in the warehouses, using barcodes that act as an information carrier. The technical equipment of warehouses for unloading semitrailers includes the use of different types of forklifts that are suited to the unloading of a given stock.

A general block diagram of the process of receiving goods into the warehouse is presented in Fig. 3. It should be remembered that each delivery is different and additional steps may be needed to properly receive the product into the warehouse.

In the process of receiving goods into the warehouse, their quantity, type, and quality must be specified along with the information on who supplies the product. Warehouse operators can only receive finished goods, of which they have been notified in advance. At this stage, goods should be prepared for the next process, which is storage. For this reason, the proper labeling of goods is a very important element. The stage that completes the process of goods receipt is the appropriate protection of products and replenishment of inventories according to the place of their storage.

An analysis of risk factors in the process of receiving goods into the warehouse relied on statistical data and a logistics audit carried out in all the examined entities for a period of 3 months. Overall, 10 risk factors were identified in the process of goods receipt.

Two tools were used to analyze risk factors: a risk map and the FMEA method. The purpose of these methods is to determine the most hazardous risk factors in the examined companies whose effect will be the most severe for the organization. The risk map is also used to classify the companies in terms of their similarity in the distribution of risk factors in the matrix of the process of goods receipt into the warehouse, whereas the results obtained from the FMEA method will provide the basis for defining preventive mechanisms for risks occurring in the process of receiving goods into the warehouse. In Table 2, risk factors in the examined enterprises are analyzed in terms of probability and outcome risk factors in warehouse.

\section{Risk matrix in a warehouse}

The risk factors in the process of receiving goods into the warehouse are analyzed. To this end, a risk map was used. The purpose of using the risk matrix is to reduce all hazards occurring during the stage of receiving goods into the warehouse down to a common denominator so that they can be mutually compared.

Each risk factor was characterized in terms of its probability (likelihood of occurrence) and possible effect (outcome, consequence). A five-level scale was used for these two parameters:

- Probability:

- $\quad<1 \%$ - very small (VS),

- $1 \%-10 \%$ - small $(\mathrm{S})$,

- $10 \%-20 \%$ - moderate $(\mathrm{M})$,

- $20 \%-50 \%-$ high $(\mathrm{H})$,

- $>50 \%$ - very high $(\mathrm{VH})$,

- Effect:

- minimal (m),

- inconsiderable (n),

- average (a),

- considerable (c),

- extreme (e).

By characterizing all risk factors in the storage process, the parameter of probability is correlated with the specificity of risk as a phenomenon, whereas the effect indicator reflects the worst consequences that a given risk factor may prompt. The Table 2 shows the probability and the effect of a given risk factor in a given company. 
Table 2. Identification of risk factors (Source: Own study)

\begin{tabular}{|l|c|c|c|c|c|c|c|c|c|c|}
\hline \multirow{2}{*}{ Risk factors } & \multicolumn{7}{|c|}{ Company } \\
\cline { 2 - 12 } & 1 & 2 & 3 & 4 & 5 & 6 & A & B & C & D \\
\cline { 2 - 11 } & \multicolumn{7}{|c|}{ Risk map - probability/outcome } \\
\hline Delivery of unsolicited goods & $\mathrm{S} / \mathrm{i}$ & $\mathrm{S} / \mathrm{i}$ & $\mathrm{VS} / \mathrm{i}$ & $\mathrm{S} / \mathrm{a}$ & $\mathrm{S} / \mathrm{m}$ & $\mathrm{S} / \mathrm{a}$ & $\mathrm{VS} / \mathrm{m}$ & $\mathrm{VS} / \mathrm{i}$ & $\mathrm{S} / \mathrm{a}$ & $\mathrm{VS} / \mathrm{i}$ \\
\hline $\begin{array}{l}\text { Receiving an incorrect quantity } \\
\text { of goods }\end{array}$ & $\mathrm{M} / \mathrm{e}$ & $\mathrm{M} / \mathrm{e}$ & $\mathrm{M} / \mathrm{i}$ & $\mathrm{M} / \mathrm{a}$ & $\mathrm{H} / \mathrm{c}$ & $\mathrm{H} / \mathrm{a}$ & $\mathrm{VS} / \mathrm{i}$ & $\mathrm{S} / \mathrm{a}$ & $\mathrm{S} / \mathrm{a}$ & $\mathrm{M} / \mathrm{m}$ \\
\hline Receiving damaged goods & $\mathrm{H} / \mathrm{c}$ & $\mathrm{H} / \mathrm{c}$ & $\mathrm{S} / \mathrm{a}$ & $\mathrm{S} / \mathrm{a}$ & $\mathrm{M} / \mathrm{i}$ & $\mathrm{S} / \mathrm{a}$ & $\mathrm{S} / \mathrm{i}$ & $\mathrm{H} / \mathrm{c}$ & $\mathrm{S} / \mathrm{e}$ & $\mathrm{M} / \mathrm{e}$ \\
\hline Hidden defects of goods & $\mathrm{M} / \mathrm{a}$ & $\mathrm{M} / \mathrm{a}$ & $\mathrm{S} / \mathrm{i}$ & $\mathrm{S} / \mathrm{a}$ & $\mathrm{VS} / \mathrm{i}$ & $\mathrm{S} / \mathrm{m}$ & $\mathrm{S} / \mathrm{i}$ & $\mathrm{M} / \mathrm{i}$ & $\mathrm{S} / \mathrm{e}$ & $\mathrm{S} / \mathrm{c}$ \\
\hline $\begin{array}{l}\text { Damaging goods when receiv- } \\
\text { ing them for storage }\end{array}$ & $\mathrm{M} / \mathrm{c}$ & $\mathrm{H} / \mathrm{c}$ & $\mathrm{S} / \mathrm{i}$ & $\mathrm{S} / \mathrm{i}$ & $\mathrm{M} / \mathrm{c}$ & $\mathrm{S} / \mathrm{c}$ & $\mathrm{S} / \mathrm{i}$ & $\mathrm{S} / \mathrm{e}$ & $\mathrm{M} / \mathrm{e}$ & $\mathrm{M} / \mathrm{e}$ \\
\hline $\begin{array}{l}\text { Receiving goods with incom- } \\
\text { plete or ill-filled documentation }\end{array}$ & $\mathrm{S} / \mathrm{a}$ & $\mathrm{S} / \mathrm{a}$ & $\mathrm{S} / \mathrm{i}$ & $\mathrm{S} / \mathrm{i}$ & $\mathrm{M} / \mathrm{i}$ & $\mathrm{VS} / \mathrm{i}$ & $\mathrm{S} / \mathrm{i}$ & $\mathrm{S} / \mathrm{i}$ & $\mathrm{M} / \mathrm{c}$ & $\mathrm{M} / \mathrm{a}$ \\
\hline Incorrect identification of goods & $\mathrm{M} / \mathrm{c}$ & $\mathrm{M} / \mathrm{c}$ & $\mathrm{S} / \mathrm{a}$ & $\mathrm{M} / \mathrm{a}$ & $\mathrm{S} / \mathrm{a}$ & $\mathrm{S} / \mathrm{c}$ & $\mathrm{S} / \mathrm{i}$ & $\mathrm{S} / \mathrm{a}$ & $\mathrm{M} / \mathrm{c}$ & $\mathrm{M} / \mathrm{c}$ \\
\hline Incorrect sorting of goods & $\mathrm{M} / \mathrm{c}$ & $\mathrm{M} / \mathrm{a}$ & $\mathrm{S} / \mathrm{a}$ & $\mathrm{VS} / \mathrm{m}$ & $\mathrm{VS} / \mathrm{i}$ & $\mathrm{M} / \mathrm{a}$ & $\mathrm{S} / \mathrm{a}$ & $\mathrm{S} / \mathrm{a}$ & $\mathrm{M} / \mathrm{c}$ & $\mathrm{S} / \mathrm{i}$ \\
\hline Incorrect labeling of goods & $\mathrm{M} / \mathrm{c}$ & $\mathrm{M} / \mathrm{c}$ & $\mathrm{S} / \mathrm{a}$ & $\mathrm{S} / \mathrm{a}$ & $\mathrm{M} / \mathrm{a}$ & $\mathrm{M} / \mathrm{c}$ & $\mathrm{S} / \mathrm{i}$ & $\mathrm{S} / \mathrm{i}$ & $\mathrm{M} / \mathrm{a}$ & $\mathrm{M} / \mathrm{i}$ \\
\hline Incorrect delivery date & $\mathrm{S} / \mathrm{c}$ & $\mathrm{M} / \mathrm{c}$ & $\mathrm{S} / \mathrm{a}$ & $\mathrm{S} / \mathrm{a}$ & $\mathrm{M} / \mathrm{a}$ & $\mathrm{M} / \mathrm{a}$ & $\mathrm{VS} / \mathrm{m}$ & $\mathrm{VS} / \mathrm{i}$ & $\mathrm{S} / \mathrm{e}$ & $\mathrm{S} / \mathrm{e}$ \\
\hline
\end{tabular}

Using Table 2, the findings were converted into numbers. Subsequently, a relationship between the outcome and the probability was calculated; this develops the risk matrix discussed in the following. Individual risk factors occurring in the process of receiving goods into a company's warehouse were entered into the relevant fields in the risk map. On the basis of the identified risk factors, risk maps for individual facilities were developed in the process of receiving goods into the warehouse.

The risk map classifies factors involved in the process of goods receipt into three groups by taking into account the probability of a risk factor and the magnitude of its effect.

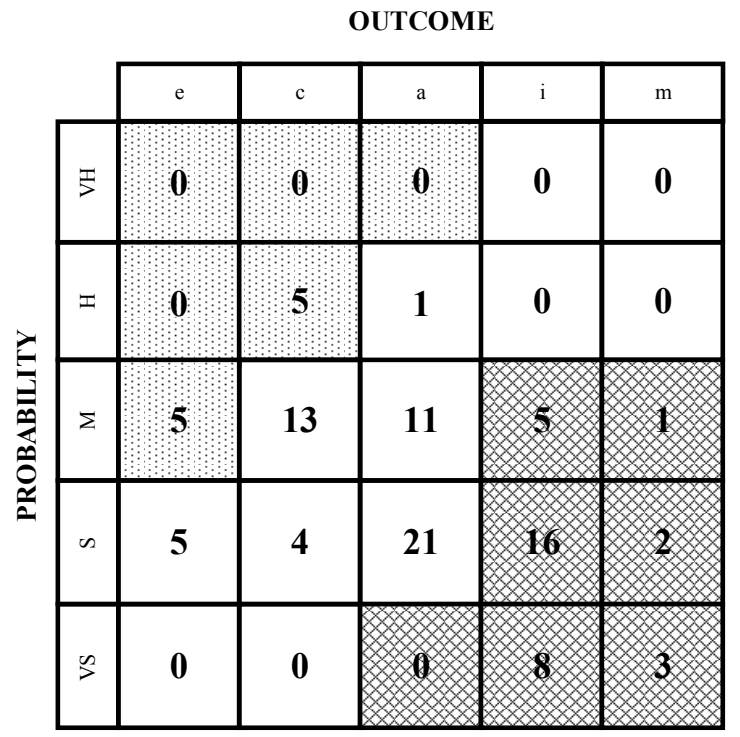

Figure 4. Risk map for examined companies (Source: Own study) 
Each of the groups was characterized below:

- Group A - VHe, VHc, VHa, He, Hc, Me - dotted area. Risk factors located in this area are most noticeable for the organization. Risks require immediate response.

- Group B - VHi, VHm, Ha, Hi, Hm, Mc, Ma, Mi, $\mathrm{Se}, \mathrm{Sc}, \mathrm{Sa}, \mathrm{VSe}, \mathrm{VSc}$ - clear area. Risk factors located in this area require constant monitoring, but compared to factors in Group A, they have less of a negative impact on the organization,

- Group C - Mm, Si, Sm, VSa, VSi, VSm hatched area. Risk factors located in this area threaten the proper functioning of the process of receiving of goods to the warehouse to a small extent.
Risk maps of the process of receiving goods into the warehouse in the examined companies are shown in Fig. 4.

There are 10 risk factors in Group A. These are the most hazardous factors for the organization. Companies should implement changes in the functioning of the goods receipt process into the warehouses with a view to eliminating the probability of these factors. It is a group with the smallest number of factors but with the most hazardous risks. In Group B, as many as 55 risk factors are identified, making it necessary to implement risk prevention mechanisms. Group C consists of 35 risk factors, and, for now, it is enough to just monitor these factors in this group.

\section{OUTCOME}

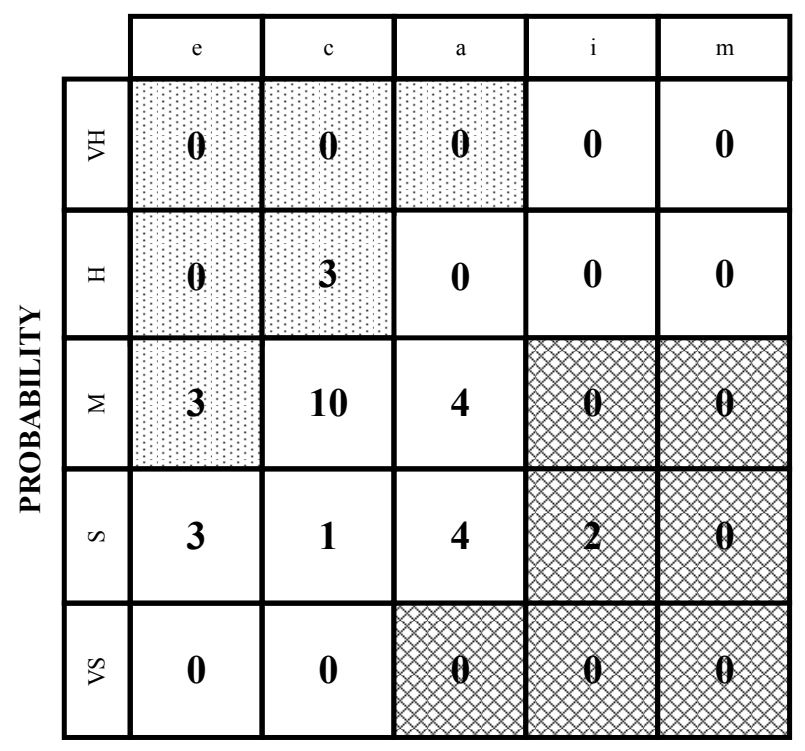

Figure 5. Risk map for Companies 1, 2, and C (Source: Own study)

Fig. 5 shows the risk map for Companies 1, 2, and C. Only two risk factors are included in Group $\mathrm{C}$ and as many as six risk factors are included in Group A. This set is characterized by a high probability of the most hazardous risk factors, with their effects being potentially the most threatening to the companies.

Fig. 6 shows the risk map for Companies 3, 4, A, and D. Risk factors are placed in all three groups, although most risks are located in Groups B and C. In Group A, there are only 2 risk factors. In these companies, constant monitoring of risk factors is required because they can change over time and become more hazardous for the organization.

Fig. 7 shows the risk map that presents factors for Companies 5, 6, and B. Determinants are spread across all three groups. The probability of risk factors is placed at a moderate level. It is a group of enterprises where the most appropriate method of risk management will involve the application of preventive mechanisms. 


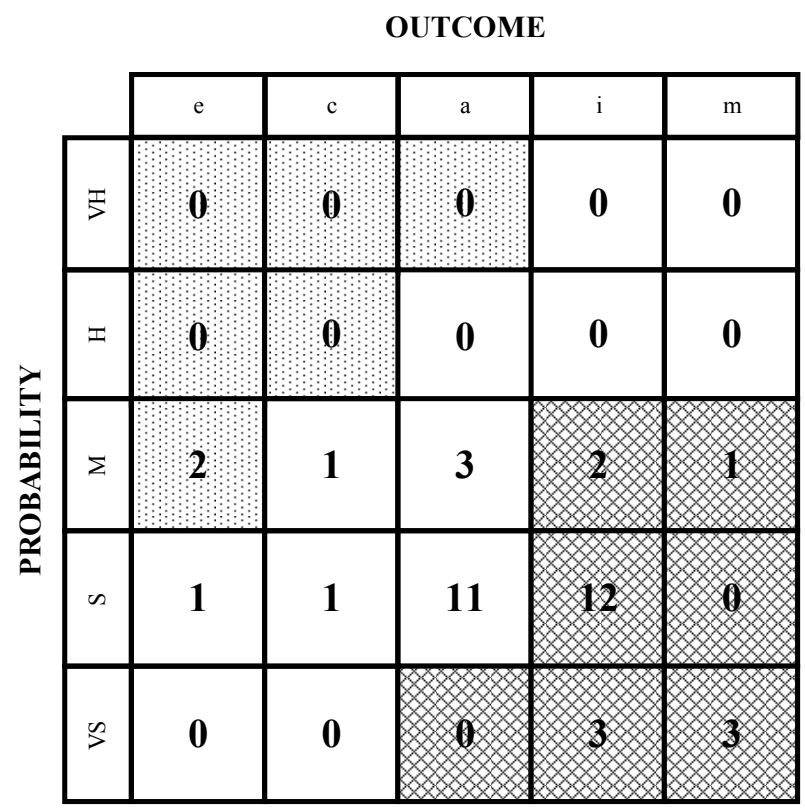

Figure 6. Risk map for Companies 3, 4, A, and D (Source: Own study)

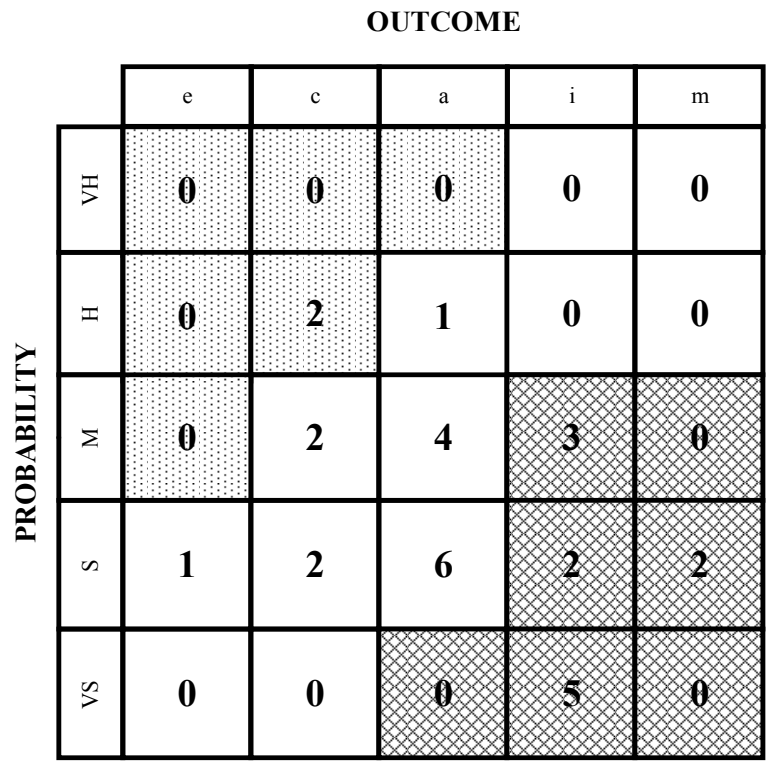

Figure 7. Risk map for Companies 5, 6, and B (Source: Own study)

\section{$7 \quad$ FMEA in a warehouse}

On the basis of on the same statistical data, the identified risk factors were analyzed again using the FMEA method, that is, the failure mode and effects analysis. The analysis consists in assigning values to three indicators, $\mathrm{O}, \mathrm{Z}$, and $\mathrm{W}$, and then applying the following formula. Risk can be calculated using the FMEA method according to the following equation (based on: Huber, 2007):

$$
\mathrm{R}=\mathrm{O} * \mathrm{Z} * \mathrm{~W}
$$

where:

$\mathrm{R}$ - is the overall risk level indicator,

$\mathrm{O}-$ is the detection of error, damage,

$\mathrm{Z}-$ is the significance of error, magnitude of effects of damage, failure,

$\mathrm{W}-$ is the probability of error (damage, failure). 
Table 3. Probability of error - indicators (W) (Source: Own study)

\begin{tabular}{|c|c|c|}
\hline Probability (\%) & Rating & Description \\
\hline $0-5$ & 1 & Low \\
\hline $6-20$ & 2 & Small \\
\hline $21-30$ & 3 & \multirow{2}{*}{ Moderate } \\
\hline $31-40$ & 4 & High \\
\hline $41-50$ & 5 & \multirow{2}{*}{ Very high } \\
\hline $51-60$ & 6 & \\
\hline $61-70$ & 7 & \\
\hline $71-80$ & 8 & \\
\hline $81-90$ & 10 & \\
\hline
\end{tabular}

Table 4. Detection of error and damage - indicators (O) (Source: Own study)

\begin{tabular}{|c|c|c|}
\hline Detection of error and damage $(\mathrm{O})$ & Rating & Description \\
\hline $91-100$ & 1 & Very high \\
\hline $71-90$ & 2 & \multirow{2}{*}{ High } \\
\hline $61-70$ & 3 & \multirow{2}{*}{ Moderate } \\
\hline $51-60$ & 4 & \\
\hline $41-50$ & 5 & Low \\
\hline $31-40$ & 6 & Impossible \\
\hline $26-30$ & 7 & 8 \\
\hline $16-25$ & 10 & . \\
\hline $6-15$ & & \\
\hline
\end{tabular}

The following criteria can also be used to assess the risk level of a particular defect/problem/cause:

- low risk - (R: 1-50),

- moderate risk - (R: 51-100),

- high risk - (R: 101-1,000).

Table 3 shows markings for risk-level indicators.

Table 4 is characterized by the indicator for the detection of error and damage
Table 5 defines the significance of error and the magnitude of the effect of damage and failure.

Table 6 shows the results of statistical data analysis for Company 2 after applying the FMEA method. Individual ratings for the specific markings of the risk-level indicator were included.

Using Table 7, risk-level indicators for all the examined enterprises were determined. 
Table 5. Significance of error and the magnitude of the effect of damage and failure - indicators (Z)

(Source: Own study)

\begin{tabular}{|c|c|c|c|}
\hline Task & Rating & $\begin{array}{c}\text { Defect } \\
\text { significance }\end{array}$ & Characteristics \\
\hline \multirow{10}{*}{$\begin{array}{l}\text { Receiving } \\
\text { goods into } \\
\text { the ware- } \\
\text { house }\end{array}$} & 1 & \multirow{2}{*}{ Very small } & \multirow{2}{*}{$\begin{array}{l}\text { The error does not cause disruption in the receipt of goods into the } \\
\text { warehouse. It requires minor corrective actions to reduce the irregu- } \\
\text { larities. }\end{array}$} \\
\hline & 2 & & \\
\hline & 3 & \multirow{2}{*}{ Small } & \multirow{2}{*}{$\begin{array}{l}\text { The error requires corrective action. No additional persons are in- } \\
\text { volved. It does not affect the remaining stages of the storage process. }\end{array}$} \\
\hline & 4 & & \\
\hline & 5 & \multirow{2}{*}{ Moderate } & \multirow{2}{*}{$\begin{array}{l}\text { The irregularity requires more people to streamline the receipt } \\
\text { of goods into the warehouse. The process of receiving goods is ex- } \\
\text { tended in time. There are additional financial costs. }\end{array}$} \\
\hline & 6 & & \\
\hline & 7 & \multirow[b]{2}{*}{ Large } & \multirow{2}{*}{$\begin{array}{l}\text { The disruption forces the reorganization of the process of receiving } \\
\text { goods into the warehouse for a specific delivery. It affects all stages } \\
\text { of the storage process. There are high additional costs associated with } \\
\text { the receipt of goods. }\end{array}$} \\
\hline & 8 & & \\
\hline & 9 & \multirow{2}{*}{ Very large } & \multirow{2}{*}{$\begin{array}{l}\text { The irregularity makes it impossible to properly receive goods into } \\
\text { the warehouse. It requires the delivery to be withheld. The error sig- } \\
\text { nificantly affects all phases of the storage process as well as the entire } \\
\text { supply chain. There are very high additional warehouse costs. }\end{array}$} \\
\hline & 10 & & \\
\hline
\end{tabular}

Table 6. FMEA for Company 2 (Source: Own study)

\begin{tabular}{|c|c|c|c|c|c|}
\hline \multicolumn{6}{|c|}{ FMEA } \\
\hline Process & Potential disruptions & $\begin{array}{l}\text { Detection of } \\
\text { error } \\
\text { and damage } \\
\text { (O) }\end{array}$ & $\begin{array}{c}\text { Significance } \\
\text { of error, magni- } \\
\text { tude of damage } \\
\text { effect }(\mathrm{Z})\end{array}$ & $\begin{array}{l}\text { Probability } \\
\text { of error } \\
\text { (W) }\end{array}$ & $\begin{array}{l}\text { Risk-level } \\
\text { indicator } \\
\mathbb{\circledR}\end{array}$ \\
\hline \multirow{10}{*}{$\begin{array}{l}\text { Receiving } \\
\text { goods into } \\
\text { the ware- } \\
\text { house }\end{array}$} & $\begin{array}{l}\text { Delivery of unsolicited } \\
\text { goods }\end{array}$ & 2 & 7 & 2 & 28 \\
\hline & $\begin{array}{l}\text { Receiving an incorrect quan- } \\
\text { tity of goods }\end{array}$ & 3 & 8 & 8 & 192 \\
\hline & Receiving damaged goods & 4 & 7 & 3 & 84 \\
\hline & $\begin{array}{l}\text { Hidden defects } \\
\text { of goods }\end{array}$ & 9 & 3 & 2 & 54 \\
\hline & $\begin{array}{l}\text { Damaging goods when re- } \\
\text { ceiving them for storage }\end{array}$ & 1 & 10 & 7 & 70 \\
\hline & $\begin{array}{l}\text { Receiving goods with in- } \\
\text { complete or ill-filled docu- } \\
\text { mentation }\end{array}$ & 4 & 5 & 3 & 60 \\
\hline & $\begin{array}{l}\text { Incorrect identification of } \\
\text { goods }\end{array}$ & 6 & 7 & 3 & 126 \\
\hline & Incorrect sorting of goods & 4 & 4 & 2 & 32 \\
\hline & Incorrect labeling of goods & 7 & 6 & 6 & 252 \\
\hline & Incorrect delivery date & 8 & 3 & 3 & 72 \\
\hline
\end{tabular}


Table 7. Risk-level indicators (Source: Own study)

\begin{tabular}{|c|c|c|c|c|c|c|c|c|c|c|}
\hline \multirow{3}{*}{ Risk factors } & \multicolumn{10}{|c|}{ Companies } \\
\hline & 1 & 2 & 3 & 4 & 5 & 6 & $\mathrm{~A}$ & $\mathrm{~B}$ & $\mathrm{C}$ & $\mathrm{D}$ \\
\hline & \multicolumn{10}{|c|}{ FMEA - risk level indicator $\mathrm{R}$} \\
\hline Delivery of unsolicited goods & 18 & 28 & 21 & 18 & 24 & 8 & 16 & 21 & 42 & 72 \\
\hline $\begin{array}{l}\text { Receiving an incorrect quantity } \\
\text { of goods }\end{array}$ & 112 & 192 & 64 & 90 & 84 & 40 & 75 & 75 & 168 & 147 \\
\hline Receiving damaged goods & 72 & 84 & 30 & 64 & 54 & 56 & 32 & 100 & 80 & 80 \\
\hline Hidden defects of goods & 126 & 54 & 45 & 54 & 40 & 48 & 40 & 105 & 72 & 48 \\
\hline $\begin{array}{l}\text { Damaging goods when receiving } \\
\text { them for storage }\end{array}$ & 54 & 70 & 56 & 56 & 100 & 105 & 50 & 54 & 70 & 140 \\
\hline $\begin{array}{l}\text { Receiving goods with incomplete } \\
\text { or ill-filled documentation }\end{array}$ & 24 & 60 & 12 & 36 & 84 & 54 & 18 & 4 & 21 & 60 \\
\hline Incorrect identification of goods & 42 & 126 & 21 & 28 & 160 & 45 & 24 & 4 & 144 & 120 \\
\hline Incorrect sorting of goods & 21 & 32 & 32 & 21 & 50 & 30 & 18 & 16 & 16 & 24 \\
\hline Incorrect labeling of goods & 144 & 252 & 70 & 42 & 90 & 54 & 24 & 24 & 168 & 120 \\
\hline Incorrect delivery date & 16 & 72 & 12 & 12 & 84 & 72 & 6 & 24 & 21 & 70 \\
\hline
\end{tabular}

Using the FMEA method, it was shown that Company 2 is the most burdened with the high probability of the most hazardous risk factors from among the outsourcing enterprises, whereas Company D is that from among the production enterprises.

The results do not, however, reveal any correlation in the magnitude of risk factors in terms of the type of storage service.

After the analyses conducted using the FMEA method and risk maps, preventive mechanisms were developed as a method of risk management. Corrective actions relate to a particular risk factor by taking into account the results obtained from the methods used (Table 8). Their implementation may reduce the likelihood of occurrence of a given risk factor, thus making the effect of the hazard less severe for the companies.

The presented preventive recommendations are appropriate for the analyzed risk factors detected in the examined companies, taking into account the applied qualitative research methods. 
Table 8. Preventive mechanisms in the goods receipt process

(Source: Own study)

\begin{tabular}{|c|c|c|c|}
\hline \multicolumn{4}{|c|}{$\begin{array}{l}\text { Preventive mechanisms } \\
\text { Process: Receiving goods into the warehouse }\end{array}$} \\
\hline $\begin{array}{l}\text { Risk } \\
\text { factors }\end{array}$ & $\begin{array}{l}\text { Potential effects } \\
\text { of risk occurrence }\end{array}$ & $\begin{array}{l}\text { Potential causes } \\
\text { of risk occurrence }\end{array}$ & Recommended actions \\
\hline $\begin{array}{l}\text { Delivery } \\
\text { of unsolicited } \\
\text { goods }\end{array}$ & $\begin{array}{l}\text { Storage of unsolicited } \\
\text { goods }\end{array}$ & $\begin{array}{l}\text { Lack of correct identifi- } \\
\text { cation of delivered prod- } \\
\text { ucts. Incorrect flow } \\
\text { of information between } \\
\text { individual elements of the } \\
\text { supply chain }\end{array}$ & $\begin{array}{l}\text { The person receiving goods is the } \\
\text { warehouse operator. } \\
\text { Before he/she takes the action of re- } \\
\text { ceiving goods into the warehouse, } \\
\text { he/she should verify the goods against } \\
\text { the documentation, that is, check the } \\
\text { sender's data. } \\
\text { All irregularities should be reported to } \\
\text { the warehouse administrator or coor- } \\
\text { dinator. }\end{array}$ \\
\hline $\begin{array}{l}\text { Receiving an } \\
\text { incorrect } \\
\text { quantity of } \\
\text { goods }\end{array}$ & $\begin{array}{l}\text { The database in the com- } \\
\text { puter system determines } \\
\text { a larger or smaller amount } \\
\text { of stock. } \\
\text { Possibility of the lack of } \\
\text { the product once the goods } \\
\text { are released from the ware- } \\
\text { house. }\end{array}$ & $\begin{array}{l}\text { Incorrect product identi- } \\
\text { fication. } \\
\text { Lack of training for the } \\
\text { employee in the area } \\
\text { of correct recognition } \\
\text { of goods in terms } \\
\text { of quantity. }\end{array}$ & $\begin{array}{l}\text { The person receiving goods should } \\
\text { always recalculate their quantity and } \\
\text { then verify the collected data against } \\
\text { the receipt document. }\end{array}$ \\
\hline $\begin{array}{l}\text { Receiving } \\
\text { damaged } \\
\text { goods }\end{array}$ & $\begin{array}{l}\text { The necessity of sending } \\
\text { back the goods to the send- } \\
\text { er or their repair. }\end{array}$ & $\begin{array}{l}\text { Damage to goods during } \\
\text { the manufacturing of the } \\
\text { product or during } \\
\text { transport to the recipient. }\end{array}$ & $\begin{array}{l}\text { Returning damaged goods to the send- } \\
\text { er. Repair of goods at the sender's } \\
\text { cost. }\end{array}$ \\
\hline $\begin{array}{l}\text { Hidden de- } \\
\text { fects of goods }\end{array}$ & $\begin{array}{l}\text { Client dissatisfaction with } \\
\text { the purchase of defected } \\
\text { goods. }\end{array}$ & $\begin{array}{l}\text { Defects that arose during } \\
\text { the manufacturing of the } \\
\text { product. }\end{array}$ & $\begin{array}{l}\text { Training in the area of correct identifi- } \\
\text { cation of product quality. }\end{array}$ \\
\hline $\begin{array}{l}\text { Damaging } \\
\text { goods when } \\
\text { receiving } \\
\text { them for } \\
\text { storage }\end{array}$ & $\begin{array}{l}\text { Necessity to incur costs } \\
\text { due to damaged goods. } \\
\text { Shortages when fulfilling } \\
\text { deliveries from the ware- } \\
\text { house. }\end{array}$ & $\begin{array}{l}\text { Insufficient training of } \\
\text { forklift operators in the } \\
\text { area of unloading goods } \\
\text { from means of external } \\
\text { transport. }\end{array}$ & $\begin{array}{l}\text { Investing in pallet boxes and modern } \\
\text { forklifts. } \\
\text { Training in the area of proper unload- } \\
\text { ing of goods from the means of exter- } \\
\text { nal transport. }\end{array}$ \\
\hline $\begin{array}{l}\text { Receiving } \\
\text { goods with } \\
\text { incomplete } \\
\text { or ill-filled } \\
\text { documenta- } \\
\text { tion }\end{array}$ & $\begin{array}{l}\text { Documentation issues } \\
\text { when fulfilling deliveries } \\
\text { from the warehouse. } \\
\text { The lack of complete and } \\
\text { correct information on } \\
\text { stored inventories. }\end{array}$ & $\begin{array}{l}\text { Preparation of incorrect } \\
\text { documentation. Insuffi- } \\
\text { cient knowledge about } \\
\text { stored goods and errone- } \\
\text { ous analysis of docu- } \\
\text { ments provided along } \\
\text { with the goods. }\end{array}$ & $\begin{array}{l}\text { By preventing the receipt of incorrect } \\
\text { or poorly completed warehouse docu- } \\
\text { mentation, the main responsible per- } \\
\text { sons are warehouse administrators. } \\
\text { When the documents are received, } \\
\text { they must verify all document data } \\
\text { against the actual state of the finished } \\
\text { product. } \\
\text { This action should be performed under } \\
\text { the supervision of the coordinator. }\end{array}$ \\
\hline
\end{tabular}


Table 8. Preventive mechanisms in the goods receipt process (cont.)

(Source: Own study)

\begin{tabular}{|l|l|l|l|}
\hline \multicolumn{5}{|c|}{ Process: Receiving goods into the warehouse } \\
\hline \multicolumn{1}{|c|}{$\begin{array}{c}\text { Risk } \\
\text { factors }\end{array}$} & $\begin{array}{c}\text { Potential effects } \\
\text { of risk occurrence }\end{array}$ & \multicolumn{1}{|c|}{$\begin{array}{c}\text { Potential causes } \\
\text { of risk occurrence }\end{array}$} & \multicolumn{1}{c|}{ Recommended actions } \\
\hline $\begin{array}{l}\text { Incorrect } \\
\text { identification } \\
\text { of goods }\end{array}$ & $\begin{array}{l}\text { Having incorrect infor- } \\
\text { mation on stored invento- } \\
\text { ries. }\end{array}$ & $\begin{array}{l}\text { Insufficient qualifications } \\
\text { in the area of inventory } \\
\text { identification. }\end{array}$ & $\begin{array}{l}\text { Using a different product identifica- } \\
\text { tion system. } \\
\text { Staff training with scanner operation } \\
\text { and correct product identification. } \\
\text { Linking the information system (data- } \\
\text { base) of the sender with the recipient } \\
\text { of the goods. }\end{array}$ \\
\hline $\begin{array}{l}\text { Incorrect } \\
\text { sorting } \\
\text { of goods }\end{array}$ & $\begin{array}{l}\text { Storing goods in the wrong } \\
\text { place. }\end{array}$ & $\begin{array}{l}\text { Insufficient qualifications } \\
\text { in terms of product sort- } \\
\text { ing. } \\
\text { Lack of knowledge about } \\
\text { which storage methods } \\
\text { are used in the ware- } \\
\text { house. }\end{array}$ & $\begin{array}{l}\text { The warehouse operator should divide } \\
\text { the goods according to the method } \\
\text { adopted for the warehouse. } \\
\text { Before transporting products to the } \\
\text { thorage area, products should be in- } \\
\text { spected by the warehouse administra- } \\
\text { tor or coordinator. } \\
\text { Designation of storage areas for the } \\
\text { process of goods receipt. }\end{array}$ \\
\hline $\begin{array}{l}\text { Incorrect } \\
\text { labeling } \\
\text { of goods }\end{array}$ & $\begin{array}{l}\text { Erroneous release of goods } \\
\text { from the warehouse. } \\
\text { Incorrect computer system } \\
\text { data about stored invento- } \\
\text { ries. }\end{array}$ & $\begin{array}{l}\text { Insufficient qualifications } \\
\text { for inventory identifica- } \\
\text { tion, leading to improper- } \\
\text { ly labeled stored } \\
\text { inventories. }\end{array}$ & $\begin{array}{l}\text { Before adding bar codes on the goods, } \\
\text { administrator should check } \\
\text { whether the data on the label matches } \\
\text { the information on the goods. } \\
\text { After affixing the inventory label, this } \\
\text { action should be verified by third par- } \\
\text { ties }\end{array}$ \\
\hline
\end{tabular}

\section{Conclusions}

When analyzing the level of risk levels obtained from the FMCG method and the risk maps, the findings can be said to agree. Most risk factors have been determined at a moderate level, which require implementation of preventive mechanisms as a risk management method. The accumulation of a large number of factors in one area may make the effects of their occurrence much more severe for the organization than initially assumed, which is why it is so important to implement changes in these areas.

The most important task of preventive mechanisms is to reduce risk factors to a minimum. One of the ways to control specific risk factors is to simply avoid them. It is much easier to reduce the magnitude of risk factors in the process of receiving goods for storage, rather than mitigating their negative consequences in subsequent storage processes, or further down in the supply chain. In both methods, however, the same most hazardous risk factors were identified:

- receiving an incorrect quantity of goods,

- receiving damaged goods,

- damage to goods during their receipt into the warehouse,

- incorrect identification of goods.

The magnitude of the effect (output, consequence) and the probability (likelihood) of risk factors depends on the value of goods as well as the continuity of the consequences that the occurrence of a risk factor entails. Hence, the identified four elements are so threatening to the examined companies. Both in production companies and outsourcing organiza- 
tions, the magnitude of these risk factors was reported at a similar level.

New risk factors may emerge in the future, which is why they should be constantly monitored and analyzed. The process of receiving goods into the warehouse should function so that it is immune to disruptions and minimizes the occurrence of risk factors by having preventive mechanisms in place to ensure efficient warehouse management.

\section{$9 \quad$ References}

[1] Brown, M.E., Chong, Y., 2000. Managing Project Risk. London: Person Education Limited.

[2] Budzik, R., Michalik, J., 2011. Procesy magazynowe $\mathrm{W}$ przedsiębiorstwie produkcyjnym ( $\mathrm{Wa}$ rehouse Processes in a Production Company). Logistyka $\mathrm{nr} 2$.

[3] Figurski, J., Niepsuj, J.M., 2017. Systemy wspomagające logistykę (Systems Supporting Logistics). Warszawa: Wyd. Wojskowa Akademia Techniczna.

[4] Dani, S., 2016. Zarządzanie łańcuchem dostaw żywności (Food Supply chain Management). Warszawa: Wyd. PWN.

[5] Huber, Z., 2007. Analiza procesu FMEA (Process Analysis FMEA). Gliwice: Wyd. Złote Myśli.

[6] Jacyna, M., Bobiński, A., Lewczuk, K., 2017. Modelowanie $i$ symulacja obiektów magazynowych (Modeling and Simulation of Warehouse Facilities). Warszawa: Wyd. PWN.

[7] Jacyna-Gołda, I., 2015. Transport Implementation Model in Supply Chains. Proceedings of 19th International Scientific Conference. Transport Means.

[8] Kaczmarek, T., 2010. Zarzadzanie ryzykiem. Ujęcie interdyscyplinarne (Risk Management. Interdisciplinary Approach). Warszawa: Wyd. Difin.

[9] Kisperska-Moroń, D., Krzyżaniak, S., 2009. Logistyka (Logistic). Poznań: Wyd. Instytut Logistyki i Magazynowania.

[10] Knight, F., 1965. Risk, Uncertainty and Profit. New York: Harper \& Row.

[11] Kulińska, E., 2011. Aksjologiczny wymiar zarzqdzania ryzykiem procesów logistycznych. Modele $i$ eksperymenty ekonomiczne (The Axiological Dimension of risk Management of Logistic Processes. Economic Models and Experiments). Opole: Oficyna Wydawnicza Politechniki Opolskiej.

[12] Kulińska, E., 2009. Podstawy logistyki i zarzadzania tańcuchem dostaw (Basics of Logistics and Supply Chain Management). Opole: Oficyna Wydawnicza Politechniki Opolskiej Akademicki Inkubator Przedsiębiorczości.

[13] Kulińska, E., Rut, J., 2016. Procesy decyzyjne w logistyce i pokrewnych obszarach badawczych. (Decision-Making Processes in Logistics and Related Research Areas). Opole: Oficyna Wydawnicza Politechniki Opolskiej.

[14] Liczmańska, K., 2016. Strategie marek produkowanych na rynku FMCG (Strategies of Brands Produced on the FMCG Market) Torun: Wyd. Naukowe Uniwersytetu Mikołaja Kopernika.

[15] Michlowicz, E., 2012. Zarys logistyki przedsiębiorstwa (Outline of the Logistics Company). Kraków: Wyd. Akademia Górniczo - Hutnicza.

[16] Miller, P., 2016. Analiza wpływu innowacyjnego narzędzia na wspomaganie działalności firm z branży FMCG na rynku Polskim (Analysis of the Impact of an Innovative Tool on Supporting the Activities of Companies from the FMCG Sector on the Polish Market). Łódź: Wyd. Uniwersytetu Szczecińskiego.

[17] Nowakowska-Grunt, J., Mesjasz-Lech, A., Kot, S., 2017. Wyzwania i perspektywy zarzadzania organizacja sieciowa. Logistyka w świetle wspótczesnych badań (Challenges and Perspectives of Managing a Network Organization. Logistics in the Light of Contemporary Research). Częstochowa: Wyd. Wydziału Zarządzania Politechniki Częstochowskiej.

[18] Nowakowski, T., 2011. Niezawodność systemów logistycznych (Reliability of Logistic Systems). Wrocław: Oficyna Wydawnicza Politechniki Wrocławskiej.

[19] Sheffi, Y., 2005. The Resilient Enterprise. Cambridge: MIT Press.

[20] Wasilewski, W., Witkowski, K., Huk, K., 2016. Ryzyko $w$ obszarze magazynowania - wybrane zagadnienia (Risk in the Area of Storage - Selected Issues). Siedlce: Zeszyty naukowe Uniwersytetu Przyrodniczo - Humanistycznego. 